\title{
Whatawhata Catchment Management Project: the story so far
}

\author{
J.M. QUINN ${ }^{1}$, M.B. DODD ${ }^{2}$ and B.S. THORROLD ${ }^{3}$ \\ ${ }^{I}$ NIWA, Private Bag Bag 11-115, Hamilton \\ ${ }^{2}$ AgResearch, Ruakura Research Centre, Private Bag 3123, Hamilton, \\ ${ }^{3}$ Dexcel, Private Bag 3221, Hamilton, New Zealand.
}

j.quinn@niwa.co.nz

\begin{abstract}
Changes in land use and management were applied to a 296 ha catchment farm at the Whatawhata Research Centre in 2000-2001 to improve its economic and environmental performance. The area had erosion and weed reversion challenges, poorly performing beef and sheep breeding enterprises, and degraded streams. Changes included conversion of the steepest land to plantation forestry; indigenous forest restoration; intensification of the farming enterprises onto easier terrain with better pasture production; changes in stock type; poplar planting for soil stabilisation; and exclusion of livestock from streams. Significant improvements have followed. The per hectare economic surplus for the pastoral enterprise improved from $30 \%$ below industry average to $13 \%$ above. The forestry enterprise will further improve economic performance in the long-term. There were reductions in the export of suspended sediment (76\%), total phosphorus (62\%), and total nitrogen (33\%). Water clarity has increased, stream temperature has declined and stream invertebrate indices indicate improvements in the fauna.
\end{abstract}

Keywords: agriculture, forestry, macroinvertebrates, riparian, water quality, nitrogen, phosphorus

\section{Introduction}

The sustainability of intensive pastoral farming in hill lands in New Zealand has come under increasing scrutiny in the last two decades due to a combination of economic, social and environmental pressures. To address this challenge, an integrated catchment management (ICM) project was established in 1996 within the 296 ha Mangaotama catchment farm at the Whatawhata Research Centre, Waikato, to explore a multiple goal approach to the management of North Island hill land. The approach involved the integration of multiple disciplines (i.e. agriculture and conservation, land and water, biology and economics), the consideration of a complex sustainable development problem (i.e. sustainable hill land management), and the mutual learning of science and society (i.e. interaction of the science team with decision makers, both policy agencies and land managers). This paper summarises the response of the farm system and stream environment to land use and practice changes implemented in 2000-2001 with the aim of improving sustainability.

\section{Methods}

\section{Study area}

The catchment farm is located in the western Waikato region of the North Island (Fig. 1), and is about $60 \%$ of the size of a typical owner-operator North Island hill farm. The land ranges from easy rolling to steep hill country. It was cleared of native (podocarp-hardwood) forest about 80 years ago and revegetated in exotic pasture species. At the beginning of the project, the farm consisted of sheep and cattle breeding enterprises ( $\sim 9$ stock units/ ha). Most of the farm is Class VI (34\%) and VII (41\%), with sedimentary/fulvic soils, under the New Zealand land use capability (LUC) system that indicates reducing versatility on a scale of I to VIII. The remainder is mainly Class V (19\%) with ash/alvic soils. Climate is wet and mild, with average annual rainfall of $1608 \mathrm{~mm}$ and temperature of $13.3^{\circ} \mathrm{C}$. The headwaters rise in steep hills (max elevation $342 \mathrm{~m}$ asl) and elevation drops to $60 \mathrm{~m}$

Figure 1 Maps of study area showing (A) initial land use before 2000 and locations of key monitoring sites and stream channels, and (B) detailed stream network and land use in the Mangaotama catchment after ICM changes in 2000, with dark and stippled areas indicating pine plantations and conservation forest and lighter areas indicating pasture.
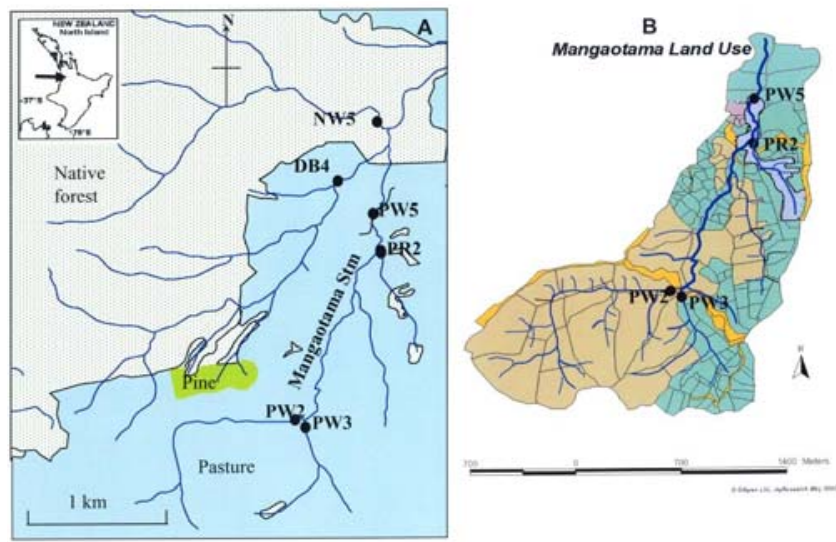
asl at the PW5 weir (Fig. 1A) where the mean discharge is $43 \mathrm{~L} / \mathrm{s}$.

\section{The Whatawhata ICM Project}

The ICM project was established in 1996 involving a group representing farmers, local government, Maori landowners, Whatawhata farm staff and researchers from several disciplines who developed the vision of a "wellmanaged rural hill country catchment" (Quinn et al. 2000). Scenarios were developed to forecast the likely effects on key indicators of different management practices (e.g. Collier et al. 2001). The conclusion of the group, when presented with the indicator data for the current land management system, was that the catchment farm was not performing well in either an economic or environmental context and a plan was developed to make progress toward the identified goals (details in Dodd et al. 2003). The steepest (Class VI and VII) land in the south-west part of the catchment was generating much of the sediment erosion and provided the lowest economic returns, while the high stream density (Fig. 1B) and large paddocks made riparian fencing for stock exclusion impractical in this part of the farm. The main theme of the ICM plan was matching land use to land capability, with a secondary theme of best management practice for each land use. Land use change in the catchment and associated management practices included (Fig. 1B):

1. Afforestation of 153 ha of mainly steep land $(60 \%$ class VII, $18 \%$ class VI and $22 \%$ class V or lower) with pine (Pinus radiata) at $1200 \mathrm{stems} / \mathrm{ha}$, leaving $10 \mathrm{~m}$ wide riparian margins on either side of all perennial streams unplanted for natural regeneration to scrub and forest. A harvest plan was drawn up to minimise harvesting impacts on erosion and streams. Analysis of forestry investment in the steeper land showed promise of much greater long-term profits, with additional benefits in reducing erosion and improving water quality. For individual landowners the issues of cashflow during implementation and farm scale need to be addressed.

2. Intensification of pastoral farming on the better contoured land. This involved a shift from breeding ewes and cows to high performance Finn-cross breeding ewe flock with Friesian-cross bulls purchased at 6 months old in autumn and sold at 18 months before their second winter. Best management practice included fencing cattle out of streams and planting poplars (approx. 1000 poles) for soil conservation on erosion prone areas still in pasture. However, there was increased tactical use of nitrogen (as urea) fertiliser to meet feed requirements of the bull beef enterprise in winter and early spring (e.g. $40 \mathrm{~kg} \mathrm{~N} / \mathrm{ha}$ applied to 7 ha in May 2000). Reactive phosphate rock and sulphur- enhanced superphosphate were applied annually in autumn by fixed wing aircraft at $24 \mathrm{~kg} \mathrm{P}$ and $30 \mathrm{~kg} \mathrm{~S}$ /ha/yr.

3. Protection and enhancement of native forest fragments by pest control (mainly targeting possums and rats), fencing from livestock access and supplementary planting. An existing 5 ha of riparian forest were extended with a further 7 ha planted with $\sim 30$ species of native shrubs and trees at $2500 \mathrm{stems} / \mathrm{ha}$.

Under a commercial owner-operator farm scenario, the changes described would be likely to take place over an extended period ( $\sim 30$ years) as farm cash flow allowed. This was the basis on which the scenarios were developed. However, for the purposes of the research project, the catchment group chose to implement these over a period of $<2$ years, commencing with poplar pole plantings in 2000 , and the forestry and conservation plantings in 2001. The livestock enterprise changes were phased in to accommodate the tree planting activities, so that the 2001-02 financial year was the first fully under the new regime.

All financial data associated with the implementation of the new land use plan were recorded by the farm manager. These included the one-off investment expenses associated with construction of new fences, pine tree planting, poplar planting, indigenous forest restoration and livestock purchases. Offset against this was the revenue from disposal of livestock no longer required, i.e. the Romney breeding ewe flock and Angus breeding cow herd.

Water flow and temperature were measured at 15minute intervals at the Mangaotama catchment weir at PW5 and weirs on the adjacent catchments with mixed land use (DB4) and native forest (NW5) (Fig. 1A). Water quality was monitored monthly at nine sites, including those in Figure 1A, as described in Quinn and Stroud (2002). Water samples were collected at the three catchment outlet weirs (PW5, DB4, and NW5, Fig. 1) from August 1996 to August 1997 for measurement of loads of sediment, nitrogen, phosphorus and dissolved organic carbon (Quinn \& Stroud 2002). Samples were also collected at the Mangaotama weir (PW5) during the previous year (August 1995-August 1996) and from September 1998 to September 2005 (methods as in Quinn $\&$ Stroud 2002). Equipment failures resulted in a gap in the data from April to July 2003, and we assumed that average sediment and nutrient concentrations during this period were the same as during the rest of the 2002-2003 monitoring year to calculate loads for that year. Water clarity (horizontal black disk visibility) was measured monthly from April 1995 to August 2007. Stream invertebrate communities were assessed at sites in the catchment and adjacent reference streams (Fig. 1A) quarterly (in June, September, December and March) 
from June 1995 to March 2002, and then twice yearly (September and March) until September 2005. Ten random invertebrate samples were collected with Surber samplers $\left(0.04 \mathrm{~m}^{2}, 250 \mu \mathrm{m}\right.$ mesh $)$ and combined to make a single sample per site that was preserved with isopropyl alcohol for analysis. In the laboratory, these samples were sorted, identified to the lowest practical level and counted. Data were used to calculate the Macroinvertebrate Community Index (MCI, species present weighted by their pollution sensitivity, Stark et al. 2001).

\section{Results and Discussion}

\section{Pasture growth and livestock performance}

Pasture production averaged $10000 \mathrm{~kg}$ dry matter/ha/yr from 2000-2004 compared with $8400 \mathrm{~kg}$ dry matter/ha/ $\mathrm{yr}$ in 1998-99. This slight increase was in line with predictions based on changing the balance of the pastoral enterprise towards a higher proportion of LUC Class V or lower land, as well as the tactical use of urea. The new pastoral enterprise is characterised by a slightly increased stocking rate (10 SU/ha, c.f. 9 previously) and slightly higher sheep:cattle winter SU ratio (65:35, c.f. 60:40), reflecting the focus on the more productive land classes and the changes to the cattle enterprise. On a per hectare basis, the key animal productivity parameters of the sheep and cattle enterprises have shown a marked improvement compared with the original farm system. Annual lamb liveweight (LW) productivity has increased from $116 \mathrm{~kg}$ LW/ha under the old system to an average over the 4 years in the new system of $203 \mathrm{~kg} \mathrm{LW} / \mathrm{ha}$, representing an increase of $75 \%$. Ewe mating weights and lamb weaning weights have shown little change, but lamb production at weaning has improved from $109 \%$ to $127 \%$ of ewes mated. Wool productivity has also increased from $23.7 \mathrm{~kg} / \mathrm{ha}$ to an average of $27.3 \mathrm{~kg} / \mathrm{ha}$, an increase of $15 \%$. Beef productivity has also increased from $86 \mathrm{~kg}$ LW/ha under the old farm system to an average of 209 $\mathrm{kg} \mathrm{LW} / \mathrm{ha}$ over 4 years under the new system, representing an increase of $143 \%$.

\section{Costs of implementation and farm economics}

The net cost of implementation of the ICM plan in the first year was approximately $\$ 260000$ (tree planting, fencing and stock purchases less stock sales). This was dominated by the cost of tree planting, with the 7 ha of native trees (19 700 plants at $\$ 142400$ ) costing 80\% of the cost of the 153 ha of pines ( $\$ 178200$ ). Additional tree management costs anticipated in the first 10 years amount to an additional $\$ 340000$, hence the total cost of implementing the land use changes is likely to amount to nearly $\$ 600$ 000. In 1998-99, before the ICM changes were in place, the annual economic farm surplus (EFS, excluding owner-operator management wage) of the 296 ha pastoral farm was well below the industry average (\$94/ha c.f. \$131/ha for the MWBES North Island hill county farm survey data, MWBES 1999). From 20012004 the now smaller (131 ha) pastoral enterprise had an average annual surplus of $\$ 285 / \mathrm{ha}, 13 \%$ above that of the industry average (\$253/ha, MWIES 2001-04). The lift in the industry average reflects increased product returns. The lift in catchment pastoral farm performance (relative to the industry average) came from increased per head performance and from removing (by afforestation) the steeper land from the pastoral farm that carried less stock and had high management costs (mainly for weed control and infrastructure maintenance). At farm scale, the annual surplus of the farm increased from $\$ 27824$ in 1998-99 to $\$ 37355$ from 2001-04. The financial returns on the half of the farm planted in pine forest are difficult to predict because they will depend on timber prices and extraction costs when the trees mature at about age $27 \mathrm{yr}$. A study in 1999 predicted an average annual cash flow after logging commenced of $\$ 187000$ / $\mathrm{yr}$ if the area had been planted and harvested progressively (c. $5 \mathrm{ha} / \mathrm{yr}$ ) (Quentin Way, unpublished report). In the meantime, there are costs to establish and maintain the planted forest (see above) that would likely require a farmer to obtain input from an outside investor to maintain an adequate financial return.

\section{Water quality}

Rapid and significant reductions occurred in loads of sediment (average down $76 \%$, ANOVA $\mathrm{F}_{1,8}=3.5$, $\mathrm{P}=0.0079$ ) and phosphorus (down $62 \%, \mathrm{~F}_{1,8}=13.2$, $\mathrm{P}=0.0083$ ) at the lower Mangaotama weir (PW5) after implementation of the land management changes (Fig. 2). Average flows were very similar in the years before and after changes, indicating that the sediment and $\mathrm{P}$ responses were due to land use changes rather than climatic variations. Pine afforestation was expected to reduce erosion as the trees develop into a forest, but the rapid reductions observed suggest that the main effects were due to stock exclusion after afforestation of the steepest part of the catchment and riparian fencing of the streams in areas that remained in pasture. Monthly measurements of water clarity at PW5 show a significant positive trend over time since ICM changes were made $\left(\mathrm{r}^{2}=9 \% \mathrm{P}=0.007\right)$, whereas no trends were apparent at the native or mixed land use reference sites.

Total nitrogen load also declined after ICM changes, though relatively less than the total phosphorus load (Fig. 2 ), due to the significant contribution of nitrate to total nitrogen (Fig. 2). Total Kjeldahl N (TKN) had a similar level of reduction to TP $(65 \& 62 \%$ respectively) after the ICM changes, indicating that the organic nitrogen is lost largely through surface flow processes. However, nitrate changed little and total $\mathrm{N}$ load only declined by 
Figure 2 Annual mean flow and loads of suspended sediment (SS), total phosphorus (TP), dissolved reactive phosphorus (DRP), total nitrogen (TN), total Kjeldahl nitrogen (TKN), nitrate, and dissolved organic carbon (DOC) at the Mangaotama weir (site PW5 Fig. 1A).

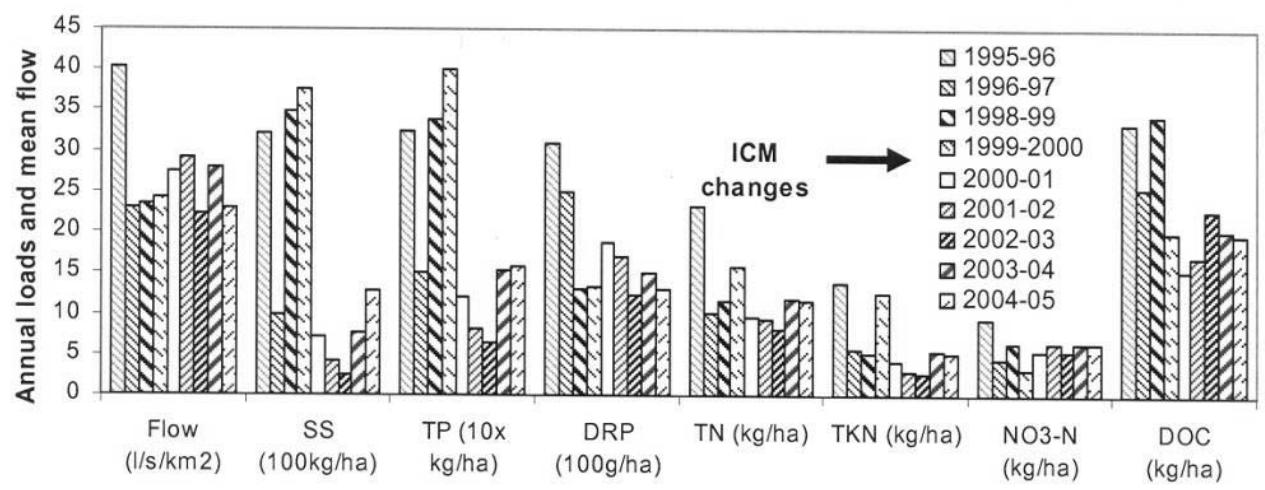

Figure 3 Trends in macroinvertebrate community index $(\mathrm{MCl})$ at four Mangaotama stream sites and adjacent mixed land use (DB4) and native forest (NW5) sites (see Fig. 1A) over 11 years, before and after ICM changes.

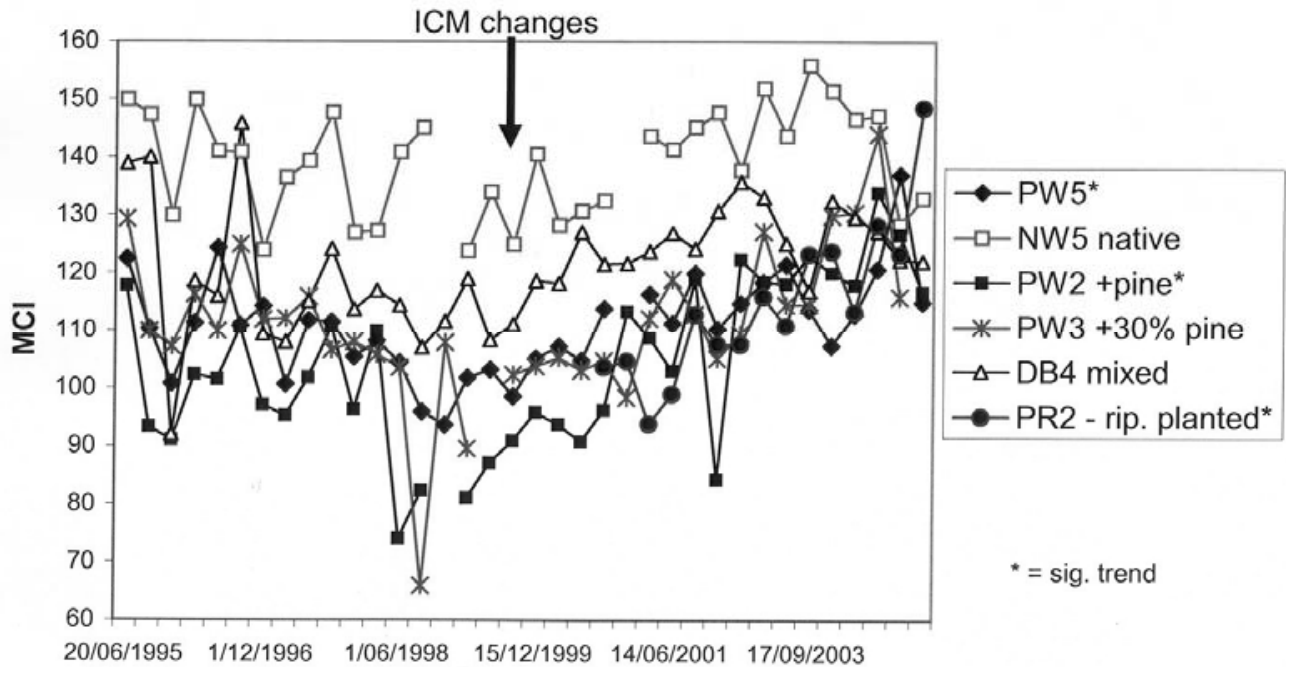

33\%. Radio-isotope studies at the 9 ha Pukemanga subcatchment at Whatawhata indicate a mean groundwater residence time of 9 years (Stewart et al. 2007). This suggests that it may be some time yet before the effects of reduced nitrate leaching to groundwater in areas planted in pines flow through to reduced groundwater nitrate concentrations and subsequent inputs to the streams. Riparian buffers in areas remaining in pasture are also expected to reduce nitrogen inputs from surface runoff and groundwaters. Ongoing monitoring will determine the net effect of these changes.

Water temperatures declined progressively at PW5 after ICM changes were made, indicating increased shading of the stream channel. The difference in annual mean temperature between PW5 and the native reference (NW5) declined from $6.5^{\circ} \mathrm{C}$ in 1999 to $1.4^{\circ} \mathrm{C}$ in 2004 and corresponding differences in annual maxima declined from $6.7^{\circ} \mathrm{C}$ to $3.8^{\circ} \mathrm{C}$.

\section{Macroinvertebrates}

The macroinvertebrate community index (MCI) showed statistically significant positive trends over the period from 1995 to 2006 (Fig. 3) at the sites downstream of riparian planting ( $\mathrm{PR} 2, \mathrm{r}^{2}=0.75, \mathrm{P}<0.0001$ ), pine afforestation ( $\mathrm{PW} 2, \mathrm{r}^{2}=0.36, \mathrm{P}=0.0002$ ), and near the catchment outlet (PW5, $\left.\mathrm{r}^{2}=14 \%, \mathrm{P}=0.025\right)$. In contrast, there were no statistically significant trends at the native forest or mixed land use reference sites (NW5 \& DB4) or at PW3 that had $30 \%$ of its catchment afforested in pines and the remainder in pasture.

Mean MCI at PW2 and PW5 during the two most recent surveys of September 2005 and March 2006 were 
122 and 126 respectively, representing $26 \%$ and $18 \%$ increases over their mean values before ICM changes.

\section{Concluding Remarks}

Farmers and resource managers need well-documented case studies to underpin sustainable land management decisions. This study demonstrated economic and environmental benefits from applying an ICM approach to define and meet multiple goals for sustainable use of hill land resources by a combination of better matching of land use and livestock enterprises to land capability and riparian management. Its findings have broad application to management of large areas on hill-lands in New Zealand. Different aspects of response to ICM implementation occur at a range of time scales and this should be recognised in the design of monitoring schemes.

\section{ACKNOWLEDGEMENTS}

Thanks to the multi-stakeholder Catchment Management Group for the time and energy they devoted to oversee the project. A large number of our colleagues were involved in data collection and analysis, in particular Terry Parminter, Bill Carlson and Alec McGowan (AgResearch) and Brian Smith, Glenys Croker, Kerry Costley, Margaret Bellingham, Kevin Collier, and the chemistry laboratory team (NIWA). This project has been funded by the New Zealand Foundation of Research Science and Technology, contracts C10X0017 to AgResearch, and C01X0305 to NIWA.

\section{REFERENCES}

Collier, K.J.; Rutherford, J.C.; Quinn, J.M.; DaviesColley, R.J. 2001. Forecasting rehabilitation outcomes for degraded New Zealand pastoral streams. Water Science and Technology 43: 175-184.
Dodd, M.; Thorrold, B.; Quinn, J. 2003. Achieving economic and environmental improvements in hill country pastoral catchments. pp. 280-283. In: Windows on a changing world. Proceedings of the 22nd New Zealand Geographical Society Conference, School of Geography and Environmental Science, University of Auckland.

MWBES. 1999: Sheep and Beef Farm Surveys. Meat and Wool Board Economic Service, Wellington, NZ.

MWIES. 2001-04. Sheep and Beef Farm Surveys. Meat and Wool Innovation Ltd. Economic Service (formerly Meat and Wool Board Economic Service), Wellington, NZ.

Quinn, J.M.; Collier, K.J.; Thorrold, B. 2000. Incorporating stream health into New Zealand hillland farm management. pp. 278-89. In: Nature Conservation 5: Nature conservation in production environments - Managing the matrix. Eds. Craig, J.L.; Mitchell, N.; Sanders, D.A. Surrey Beatty and Sons, Chipping Norton.

Quinn, J.M.; Stroud, M.J. 2002. Water quality and sediment and nutrient export from New Zealand hillland catchments of contrasting land use. New Zealand Journal of Marine and Freshwater Research 36: 409429.

Stark, J.D.; Boothroyd, I.K.G.; Harding, J.S.; Maxted, J.R.; Scarsbrook, M.R. 2001. Protocols for sampling macroinvertebrates in wadeable streams. New Zealand Macroinvertebrate Working Party Group Report No. 1. Ministry for the Environment, Wellington. 57 pp. Stewart, M.K.; Mehlhorn, J.; Elliott, S. 2007. Hydrometric and natural tracer (oxygen-18, silica, tritium and sulphur hexafluoride) evidence for a dominant groundwater contribution to Pukemanga Stream, New Zealand. Hydrologic Processes. Published on line DOI: 10.1002/hyp.6557. 